\title{
THE USE OF TWO RADIOACTIVE ISOTOPES OF IRON IN TRACER STUDIES OF ERYTHROCYTES ${ }^{1}$
}

\author{
By WENDELL C. PEACOCK, ROBLEY D. EVANS, JOHN W. IRVINE, JR., \\ WILFRED M. GOOD, ARTHUR F. KIP, SOMA WEISS, 2 \\ AND JOHN G. GIBSON, 2ND \\ (From the Radioactivity Center, Massachusetts Institute of Technology, Cambridge; the \\ Medical Clinic of the Peter Bent Brigham Hospital, and Department \\ of Medicine, Harvard Medical School, Boston)
}

(Received for publication January 18, 1946)

\section{INTRODUCTION}

There are 2 radioactive isotopes of iron suitable for use as biological tracers. One of these, $\mathrm{Fe}^{59}$, has a half life of 47 days and emits gamma rays and low energy beta rays. The other, $\mathrm{Fe}^{55}$, has a half life of about 5 years and emits low energy $x$-rays only.

This paper describes how these 2 isotopes are prepared for red blood cell tracer studies, how biological samples containing the radioactive iron are prepared for measurements, how the measurements are performed, and how the results are reported to collaborating medical research teams engaged in various physiological and clinical studies.

$\mathrm{Fe}^{59}$ has been in use for a number of years for metabolism and red cell studies ( 1 to 5 ) and a method of preparing samples for measurement with a thin window beta ray counter has been described by Ross (6). The longer lived isotope, $\mathrm{Fe}^{55}$, on the other hand, appears not to have been used previously.

Each isotope has characteristics that make it particularly useful in certain problems; the combined use of both tracers offers solutions of problems which cannot be obtained by the employment of either isotope alone.

\section{PREPARATION OF THE ISOTOPES}

a. Nuclear bombardment. Bombardment of iron with deuterons yields both isotopes mixed. The earlier work of Hahn et al. (1 to 5) and

1 The work described in this paper was done under a contract, recommended by the Committee on Medical Re- search, between the Office of Scientific Research and Development and the Massachusetts Institute of Technology, in collaboration with the Peter Bent Brigham Hospital.

2 Deceased, January 31, 1942.
Ross (6) used these mixed isotopes, but their radioactivity detection apparatus was sensitive only to the radiations from $\mathrm{Fe}^{59}$. The nuclear reactions are $\mathrm{Fe}^{58}(\mathrm{~d}, \mathrm{p}), \mathrm{Fe}^{59}\left(\mathrm{Fe}^{58}\right.$, a stable isotope, bombarded with deuterons, $\mathrm{d}$, forms, through the liberation of a proton, $\mathrm{p}, \mathrm{Fe}^{59}$ ) and $\mathrm{Fe}^{54}$ (d, p) $\mathrm{Fe}^{55}$. When iron is bombarded, these 2 isotopes are produced simultaneously, and cannot be isolated thereafter in a state of radioactive purity.

By deuteron bombardment of manganese, the reaction $\mathrm{Mn}^{55}$ (d, 2n) $\mathrm{Fe}^{55}$ occurs and only the long-lived radioactive iron isotope is obtained. The manganese targets are prepared from an alloy of manganese ( 90 per cent $\mathrm{Mn}, 8$ per cent $\mathrm{Cu}$, 2 per cent $\mathrm{Si}$ ) which has suitable mechanical and thermal properties. This alloy is cast into $1 / 8$-inch slabs and machined down to $1 / 32$-inch thickness. Targets $1 / 2 \times 1$ inch are cut from this material and silver soldered to the oscillating probe target described by Livingston (7). Evaporation of the target face limits the deuteron beam current to $100 \mu \mathrm{a}$ at $14 \mathrm{MEV}$. Under these conditions our cyclotron yields of $\mathrm{Fe}^{55}$ have been approximately $2 / 3$ of a microcurie per microampere hour.

The shorter-lived isotope, $\mathrm{Fe}^{59}$, can be produced in pure form by the bombardment of cobalt with neutrons, through the nuclear reaction $\mathrm{Co}^{59}(\mathrm{n}, \mathrm{p})$ $\mathrm{Fe}^{59}$. Deuteron bombardment of cobalt also yields $\mathrm{Fe}^{59}$ as a by-product of the fast neutrons always present with deuteron reactions. Because thin cobalt targets are necessary for thermal conduction, and the total amount of cobalt is small ( 1 to 2 grams), this is not an efficient method of producing high $\mathrm{Fe}^{59}$ activities. If a comparatively large piece of cobalt (about 40 grams) is soft soldered to the back of a beryllium target the larger amount of cobalt, higher permissible beam currents on $\mathrm{Be}$, and much higher neutron yield 
from the $\mathrm{Be}^{9}(\mathrm{~d}, \mathrm{n}) \mathrm{B}^{10}$ reaction, give much better yields of $\mathrm{Fe}^{59}$. Using beryllium, our yields have been approximately 0.023 microcuries per microampere hour.

b. Radiochemical preparation. Regardless of the mode of formation of the radioactive iron, the purification and preparation of material for use is essentially the same in all cases. The target material $\mathrm{Fe}, \mathrm{Mn}$, or $\mathrm{Co}$ is dissolved in concentrated hydrochloric acid, diluted and filtered. If manganese and cobalt of high purity are used it is necessary to add 1 to $10 \mathrm{mgm}$. of inactive $\mathrm{Fe}^{+++}$ as a carrier. Usually there is enough iron in the target so that such additions are unnecessary. After oxidation of the iron from $\mathrm{Fe}^{++}$to $\mathrm{Fe}^{+++}$ with $\mathrm{H}_{2} \mathrm{O}_{2}$ the iron is precipitated as $\mathrm{Fe}(\mathrm{OH})_{3}$ with pyridine (8).

The precipitate of $\mathrm{Fe}(\mathrm{OH})_{3}$ is dissolved in $6 \mathrm{M}$ $\mathrm{HCl}$, and $10 \mathrm{mgm}$. each of $\mathrm{Mn}, \mathrm{Co}$ and $\mathrm{Zn}$ added as carriers to aid in eliminating the radioactive isotopes of these elements from the iron. Ferric hydroxide is again precipitated with pyridine, leaving the $\mathrm{Mn}$, Co and $\mathrm{Zn}$ in solution. This precipitation procedure is repeated 2 to 4 times until the activity in the filtrate is low.

After elimination of these 3 elements, the hydrogen sulphide group is eliminated by adding 50 mgm. of $\mathrm{Cu}^{++}$as carrier for this group, and precipitating the sulphide with $\mathrm{H}_{2} \mathrm{~S}$ from a $0.1 \mathrm{M}$ $\mathrm{HCl}$ solution. The preciptate is filtered off and discarded. The filtrate is boiled to eliminate $\mathrm{H}_{2} \mathrm{~S}$, $\mathrm{Fe}^{++}$is oxidized to $\mathrm{Fe}^{+++}$with $\mathrm{H}_{2} \mathrm{O}_{2}$, and $\mathrm{Fe}(\mathrm{OH})_{3}$ is preciptated with $\mathrm{NH}_{4} \mathrm{OH}$. This precipitate is dissolved in $1.5 \mathrm{M} \mathrm{H}_{2} \mathrm{SO}_{4}$, and $10 \mathrm{mgm}$. of indium is added (radioactive indium is formed from the cadmium in the silver solder used). Precipitation of $\mathrm{Fe}^{+++}$with cupferron leaves the indium behind in the filtrate.$(9)$. The cupferron precipitate is carefully ignited, the $\mathrm{Fe}_{2} \mathrm{O}_{3}$ dissolved in concentrated $\mathrm{HCl}$, diluted to $3 \mathrm{M}$, indium carrier added and the precipitation with cupferron repeated. This precipitate is ignited, dissolved in concentrated $\mathrm{HCl}$, diluted, filtered (to remove unburned carbon which usually is present after igniting the cupferron precipitate) and the iron reprecipitated as $\mathrm{Fe}(\mathrm{OH})_{3}$ with $\mathrm{NH}_{4} \mathrm{OH}$. This preciptate is carefully ignited in a weighed crucible and the $\mathrm{Fe}_{2} \mathrm{O}_{3}$ weighed to determine the weight of iron present.
The final step in the preparation of the iron is to synthesize it into a compound suitable for intravenous use in animals and humans. Ferric ammonium citrate, in doses described below, has been found safe for intravenous injection. After dissolving the $\mathrm{Fe}_{2} \mathrm{O}_{3}$ in concentrated $\mathrm{HCl}$ and diluting, $\mathrm{Fe}(\mathrm{OH})_{3}$ is again precipitated with $\mathrm{NH}_{4} \mathrm{OH}$ and is well washed with distilled water. The precipitate is dissolved in a solution containing 3 moles of citric acid for each mole of iron present. Warming the mixture hastens the solution of the precipitate. When the precipitate is completely dissolved the solution is brought to a $\mathrm{pH}$ of 7.0 with $\mathrm{NH}_{4} \mathrm{OH}$ and filtered into a clean bottle.

This solution can be diluted with neutral distilled water to obtain any desired concentration of iron. It withstands sterilization by autoclaving if sealed in glass ampouls, but heating in open containers may result in the formation of a precipitate. Ferric ammonium citrate is photosensitive and should be kept in the dark to avoid precipitation. The compound does not inhibit the growth of common molds.

\section{PREPARATION OF RADIOACTIVE RED CELLS}

When radioactive ferric ammonium citrate is injected intravenously into animals or humans it is rapidly removed from the blood stream. A large portion of the iron is retained in the body tissues concerned with iron storage. Hahn et al. (10) gave ferric ammonium citrate to dogs and assayed liver and spleen for both ferritin and radioactive iron, and found a relatively high level of radioactivity in the ferritin iron. It therefore seems highly probable that the radio-iron becomes intimately mixed with all of the body iron stores present when the isotope was injected, and is hence available for hematopoietic needs.

It is generally believed that hemoglobin is "laid down" inside the developing erythrocyte. If some of the iron atoms involved in this synthesis are radioactive, a proportionate number of them will become an integral part of the new hemoglobin molecule within the newly developed cell. When the cell is released into the circulation, its presence in the blood stream can be detected as long as it remains morphologically intact. When the tagged red cell is destroyed, its 
hemoglobin derived iron is very rapidly removed from the plasma, to be reused, to some extent at least, in the synthesis of new hemoglobin.

In general, each red cell contains approximately 0.1 per cent iron, or about a thousand million atoms of iron. In the radioactive donors, between 1 and 10 of these iron atoms contains a radioactive nucleus, the vast majority of the iron atoms in each red cell being ordinary stable iron.

It has been demonstrated experimentally that there is no exchange of the radioactive iron in the red cells, either with plasma in vitro or in vivo, or with saline in vitro. Thus the method differs in important respects from the labelling of red blood cells by absorbed carbon monoxide (11) or by adsorbed radioactive phosphorus (12). It furnishes a specific method of detecting the advent of new red cells, and to a certain extent, of following their fate in the circulation, and the disposition made of their contained iron.

The normal human erythrocyte is thought to have a life expectancy of about 100 days. Within this period it is possible to estimate the age of the oldest tagged cell in the circulation of a subject who has been given radio-iron. When these cells are removed from circulation some part of their contained radio-iron will eventually re-enter the circulation in the hemoglobin of new cells. If this "turnover" be allowed to continue for a sufficient period of time, the tagged cells will be of all ages from birth to death, or representative of a "mixed age population" of cells. The administration of the alternate radioactive isotope of iron at such a time will result in the production of new cells, the presence of which can be differentiated from the presence of "mixed age cells." Thus the behavior of young and old cells may be studied in the same subject.

Hemoglobin solutions prepared from cells obtained from donors prepared with either or both isotopes can also be used as radioactive tracer material.

The utilization of radio-iron, either when given as a ferric salt or as dissolved hemoglobin, or resulting from the postinfusion breakdown of tagged red cells, as well as the application of the "double tracer" technique to a wide variety of experimental and clinical studies will be discussed in subsequent communications $(13,14)$.

\section{PREPARATION OF BLOOD SAMPLES FOR RADIOACTIVE MEASUREMENT}

Both of the iron isotopes have radiations that are readily absorbed in a thick sample of material. Thus, for maximum detection efficiency all of the iron must be separated from extraneous, material, and the metal plated as a thin uniform film on a metal planchet. In this form it can be placed close to the window of the counter tube used to measure the activity. This separation is accomplished by wet ashing the sample and precipitating the iron.

The aliquot of donor cells, or the recipient's packed cells are transferred, with adequate rinsing with water, to a $500 \mathrm{ml}$. Kjeldahl flask, and concentrated $\mathrm{H}_{2} \mathrm{SO}_{4}$ added. Three to $5 \mathrm{ml}$. is adequate for donor, and $10 \mathrm{ml}$. for recipient samples. Inactive iron is added to bring the total iron content of the sample to $10 \mathrm{mgm}$. It may be assumed that $1 \mathrm{ml}$. of packed red cells contains 1 mgm. of $\mathrm{Fe}$. A solution of $\mathrm{FeCl}_{3}$ containing 5 mgm. Fe per $\mathrm{ml}$. is convenient. The inactive iron should be added before digestion.

The acid mixture is slowly brought to a boil over a bunsen burner. Glass beads aid in reducing foaming and bumping. When the water has boiled off and the acid starts to fume, $1 \mathrm{ml}$. of 60 per cent $\mathrm{HClO}_{4}$ is added, slowly, and this is repeated a few times until digestion is complete. Not more than $4 \mathrm{ml}$. of $\mathrm{HClO}_{4}$ should be added to the original $10 \mathrm{ml}$. of acid, and it should never be added if the $\mathrm{H}_{2} \mathrm{SO}_{4}$ has boiled dry, as an explosive compound is formed. As digestion proceeds, the boiling becomes less violent, and more heat can be applied. When digestion is complete the liquid will be a straw yellow color when hot. On cooling it becomes colorless and a chalk white precipitate settles out. All organic matter must be completely oxidized or the subsequent precipitation of iron may be incomplete.

The acid residue is then transferred to a 100 $\mathrm{ml}$. centrifuge tube with 1 or 2 washings with 0.1 $\mathrm{N} \mathrm{H}_{2} \mathrm{SO}_{4}$. The iron is then precipitated by the addition of concentrated $\mathrm{NH}_{4} \mathrm{OH}$ to slightly beyond the neutral point. A fine brown precipitate which becomes flocculent appears at the end point. A mechanical stirrer increases the speed with which ammonia can be added. The tube is centrifuged at 1200 r.p.m. for 10 minutes and the 
supernatant fluid removed by suction. Since the precipitate is fine, it is well to use a filter paper over the end of the suction tube. The iron is then ready for electrolytic deposition on the copper counting planchets.

Iron can be plated quantitatively from an ammonium oxalate-oxalic acid solution (15). The technique of electroplating described herein is a modification of the method of Ross (6). The $\mathrm{Fe}(\mathrm{OH})_{3}$, in the centrifuge tube in which it was precipitated, is dissolved in $0.5 \mathrm{ml}$. of $3 \mathrm{M} \mathrm{H}_{2} \mathrm{SO}_{4}$. This solution is transferred to the plating cells (Figure 1), using a saturated ammonium oxalate solution. The final volume is about $25 \mathrm{ml}$., and the $\mathrm{pH}$ of the solution is 4 to 5 .

Electrolysis is carried out at 0.9 amp. with a voltage drop across the cell of about 6 to 8 volts. Six cells are run in series to avoid unnecessary power dissipation when $110 \mathrm{v}$. DC is used as a source of current. A small rheostat and an ammeter serve as a control and a monitor for the groups. Provision is made for shunting each cell through a 6 to 8 volt light bulb of the proper resistance so that any number of the 6 cells can be used at once. At the end of an hour the $\mathrm{pH}$ of the solution is tested. If it is greater than $\mathrm{pH} 7$,

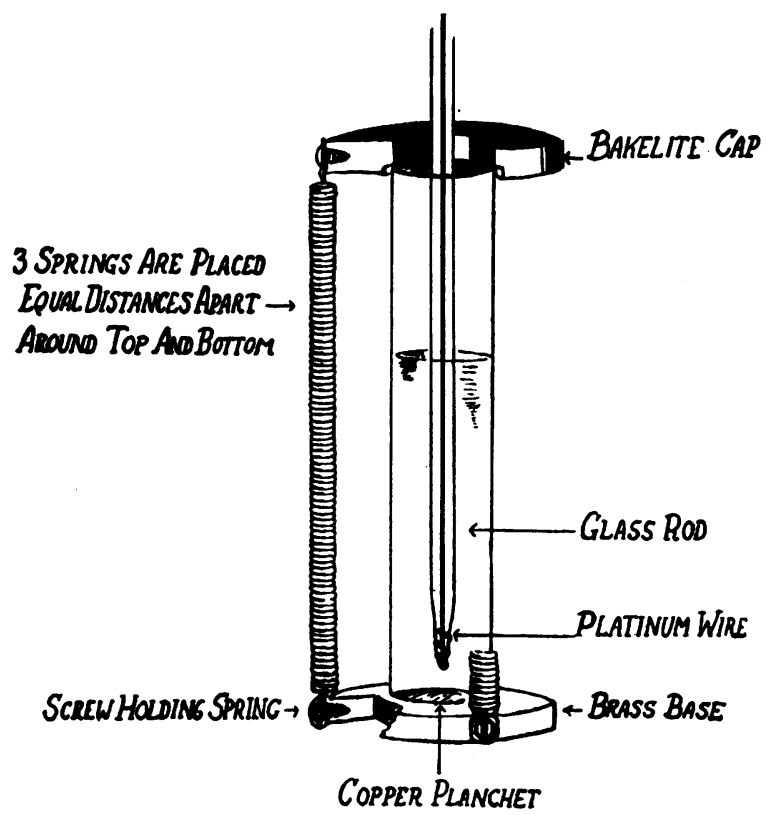

Fig. 1. Semi-diagrammatic View of the Apparatus for Electroplating Iron on Planchets from Solution, Assembled

Each unit has individual motor drive. a few drops of $3 \mathrm{M} \mathrm{H}_{2} \mathrm{SO}_{4}$ are added to bring it down to about $\mathrm{pH} \mathrm{6}$, and electrolysis is continued for a total of 1.5 hours. A $0.5 \mathrm{ml}$. sample is withdrawn and tested for completeness of deposition of the iron. If this sample contains more than $0.0006 \mathrm{mgm}$. of iron, the $\mathrm{pH}$ is readjusted to between 6 and 7 , and the plating continued for another half hour.

In testing for iron, advantage is taken of the intense red color developed when ferrous iron is treated with $a, a^{\prime}$ dipyridyl in an acid solution. The sample to be tested is made acid with a drop of $3 \mathrm{M} \mathrm{H}_{2} \mathrm{SO}_{4}$ and 1 drop each of 1 per cent $a, a^{\prime}$ dipyridyl in $0.5 \mathrm{M} \mathrm{HCl}$ and 10 per cent $\mathrm{NaHSO}_{3}$ is added. Gentle warming develops the color in about 2 minutes. The amount of iron in solution is determined by comparing the color developed with permanent color standards in a simple color comparator. These standards are made by visual matching of cobalt chloride solutions with the color developed in iron solutions of known concentrations. When properly matched, the standards are sealed into small $100 \mathrm{~mm}$. test tubes and permanently mounted in the comparator.

After the iron has been completely plated from the solution (less than $0.0012 \mathrm{mgm}$. per $\mathrm{ml}$. remaining) the planchet is removed and dried with an air blast. It is then coated with a film of light machine oil diluted with benzene $1: 100$.

The sample is now on a copper planchet 1 inch in diameter and 0.02 inch thick (a form readily available commercially). The iron film forms a circle $7 / 8$ inch in diameter and contains $10 \mathrm{mgm}$. of iron or $2.6 \mathrm{mgm}$. Fe per $\mathrm{cm}^{2}$. It is now ready for measuring.

COUNTERS WHICH DIFFERENTIATE BETWEEN THE

TWO RADIOACTIVE ISOTOPES OF IRON ON A

BASIS OF THEIR NUCLEAR SPECTRA

Deutsch et al (16) in cooperation with the authors made a study of the radiations emitted by $\mathrm{Fe}^{59}$ (47 day half-life). They found that this isotope disintegrates by either of 2 similar processes, each with about the same probability of occurrence. In one case a beta ray, or energetic electron, is emitted with 0.46 million electron volts (MEV) maximum energy, followed by a gamma ray of $1.10 \mathrm{MEV}$. In the alternate method of disintegration the beta ray has a maximum energy 
of $0.26 \mathrm{MEV}$, and is followed by a gamma ray of 1.30 MEV. In either case, the beta rays emitted have an average energy of only about $1 / 3$ that of the maximum. The average energy of all the beta rays is then only about $0.12 \mathrm{MEV}$.

Beta rays are absorbed to about the same extent by equal masses of any material, the fraction transmitted through any in particular being dependent upon the initial energy of the individual beta rays. The counters used for measuring $\mathrm{Fe}^{59}$ are filled with helium to about $70 \mathrm{~cm}$. $\mathrm{Hg}$ pressure and they have a mica window approximately 10 microns thick. The effect of the counter window thickness on the transmission of these beta rays is shown in Figure 2. This emphasizes the advantage of using thin counter windows when measuring $\mathrm{Fe}^{59}$ (6).

$\mathrm{Fe}^{55}$ (5 year half-life) disintegrates into $\mathrm{Mn}^{55}$, a stable isotope, when the nucleus captures an electron from one of the inner orbits of the atom. This process, "orbital electron capture," leaves a vacancy in one of the inner electron shells which is subsequently filled by an electron from an outer shell. As a result, an x-ray characteristic of the $\mathrm{Mn}^{55}$ atom may be emitted. The most abundant and most energetic $\mathrm{x}$-ray emitted has an energy of 5.9 kilovolts $\left(\mathrm{K}_{a_{1}}\right.$ line of $\mathrm{Mn}$ ). One of these $\mathrm{x}$ rays leaves the atom in about 24 per cent of the disintegration. ${ }^{3}$ Any radiation other than this one $\mathrm{x}$-ray that might be expected in connection with

3 This $x$-ray can be emitted only if a $K$ shell electron is captured, about 80 per cent of the cases, and in only 30 per cent of these $\mathrm{K}$ capture processes is an $\mathrm{x}$-ray emitted from the atom. In the other 76 per cent of the cases, low energy electrons (Auger electrons) and $\mathrm{L}$ and $\mathrm{M}$ x-rays are liberated but are not detected.

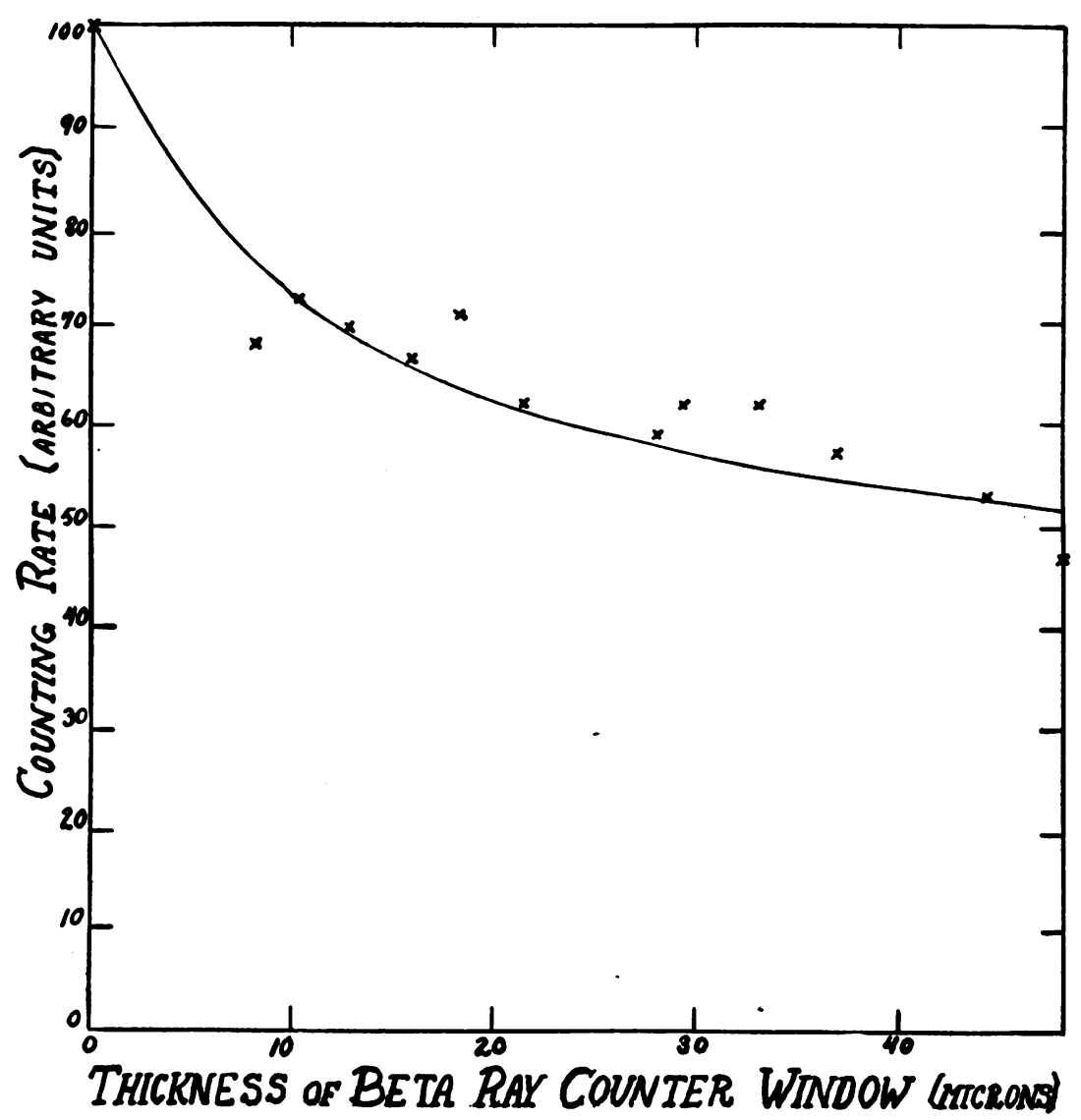

Fig. 2. The Effect of Varying Thickness of Mica Counter Window on the Counting Rate of a Sample of FE$_{E^{59}}$

The experimental point where no counter window was used was normalized to 100 . 


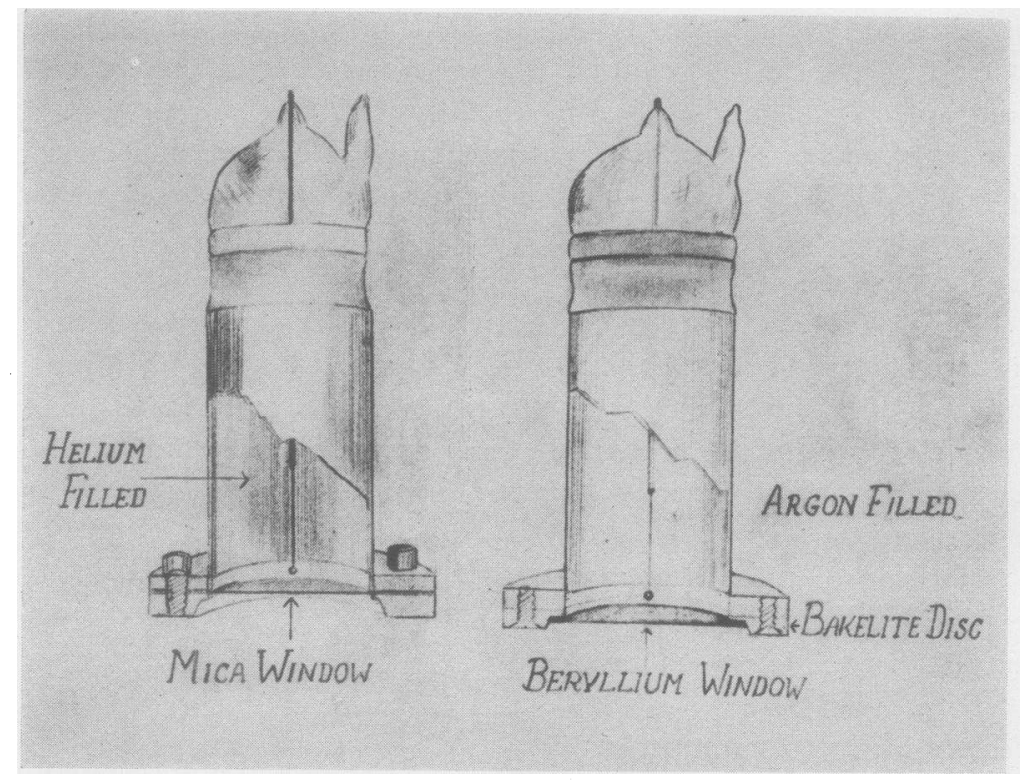

Fig. 3. The Helium Filled Counter Used to Measure Beta Rays FROM FE IS $^{5}$ Shown ON THE LEFT

The argon filled counter for detection of $\mathrm{x}$-rays from $\mathrm{Fe}^{55}$ is shown on the right. The counters are differential since the $x$-rays are not absorbed in the helium, and beta rays are absorbed in the beryllium window.

this disintegration (e.g.: gamma rays, conversion electrons, etc.) has not been observed with our present detection techniques. Table I lists the mass absorption coefficients and the thicknesses of various materials necessary to attenuate this $0.0059 \mathrm{MEV} \mathrm{x}$-ray to half value. In every case the absorption is exponential. The striking thing that will be noted, besides the relatively small amount of material necessary to absorb the radiation, is the side difference in the absorbing power for the same mass of different materials (proportional to the cube of the atomic number).

Thus a 10 micron mica window would transmit 57 per cent of the $\mathrm{x}$-radiation, and a beryllium window $0.76 \mathrm{~mm}$. thick would transmit 55 per cent of the $\mathrm{x}$-radiation. Such a beryllium window would transmit less than 5 per cent of the beta rays from the 47 day iron isotope, while a 10 micron mica window will transmit 75 per cent of the beta rays.

Any agent that will produce ionization in the "counting volume" of a Geiger Counter will cause it to "count." In order for the x-ray to be counted it must be absorbed in the gas of the counter, or near enough to the surface of the walls so that electrons formed by the x-ray will get to the counting volume. In order for the $\mathrm{Ka} \mathrm{x}$-ray of $\mathrm{Mn}$ to cause a count it must be absorbed either in the gas of the counter, or in the walls of the counter at a depth not greater than would be covered by $14 \mathrm{mgm}$. per $\mathrm{cm}^{2}$.

Thus it is found that a counter with a beryllium window thick enough to stop 47 day iron beta rays and filled with argon gas at $60 \mathrm{~cm}$. $\mathrm{Hg}$ pressure detects about 30 times as many $\mathrm{x}$-rays as the 10 micron mica window counter filled with helium at $70 \mathrm{~cm} . \mathrm{Hg}$ pressure.

These two types of counters (Figure 3 ) are useful in double tracer experiments, since each will detect the presence of one isotope and is almost completely insensitive to the other.

Ross (6) has already pointed out that with the 47 day isotope the fraction of beta rays absorbed within a source of the present geometry $(2.6 \mathrm{mgm}$. per $\mathrm{cm}^{2}$ ) is negligible, but that an appreciable fraction of the beta rays are absorbed as the source gets thicker (approximately 10 per cent are absorbed with a $5.2 \mathrm{mgm}$. per $\mathrm{cm}^{2}$ source).

Figure 4 shows the effect on counting rate of plating increasing amounts of inactive iron with 
sample containing the same amount of $\mathrm{Fe}^{55}$. The curve is proportional to $\frac{1-e-N t}{N t}$ where $N$ is the mass absorption coefficient of $\mathrm{K}$ Mn x-rays, $e$ is the base of the natural logarithm, and $t$ is the thickness of the iron in grams per $\mathrm{cm}^{2}$. The points represent measured activities using increasing amounts of stable iron. There is approximately 1 per cent self absorption per mgm. of sample under these conditions. One readily sees from this figure that it is even more important to keep constant sample weight in the case of $\mathrm{Fe}^{55}$. than with $\mathrm{Fe}^{59}$.

\section{SAMPLE MEASUREMENTS}

The copper planchets on which the iron has been plated are placed on a turntable which automaticaly places one sample after the other under the counters which are to measure the activities of the iron (Figure 5). Each sample is feasured for a predetermined time interval (usually 15 or 30 minutes). As a new sample comes under the counter its counts begin to register on a countingrate-meter. The average counting rate is registered in ink on the tape of a recording milliammeter. If both iron isotopes are used in the experiment the records from a beta ray counter

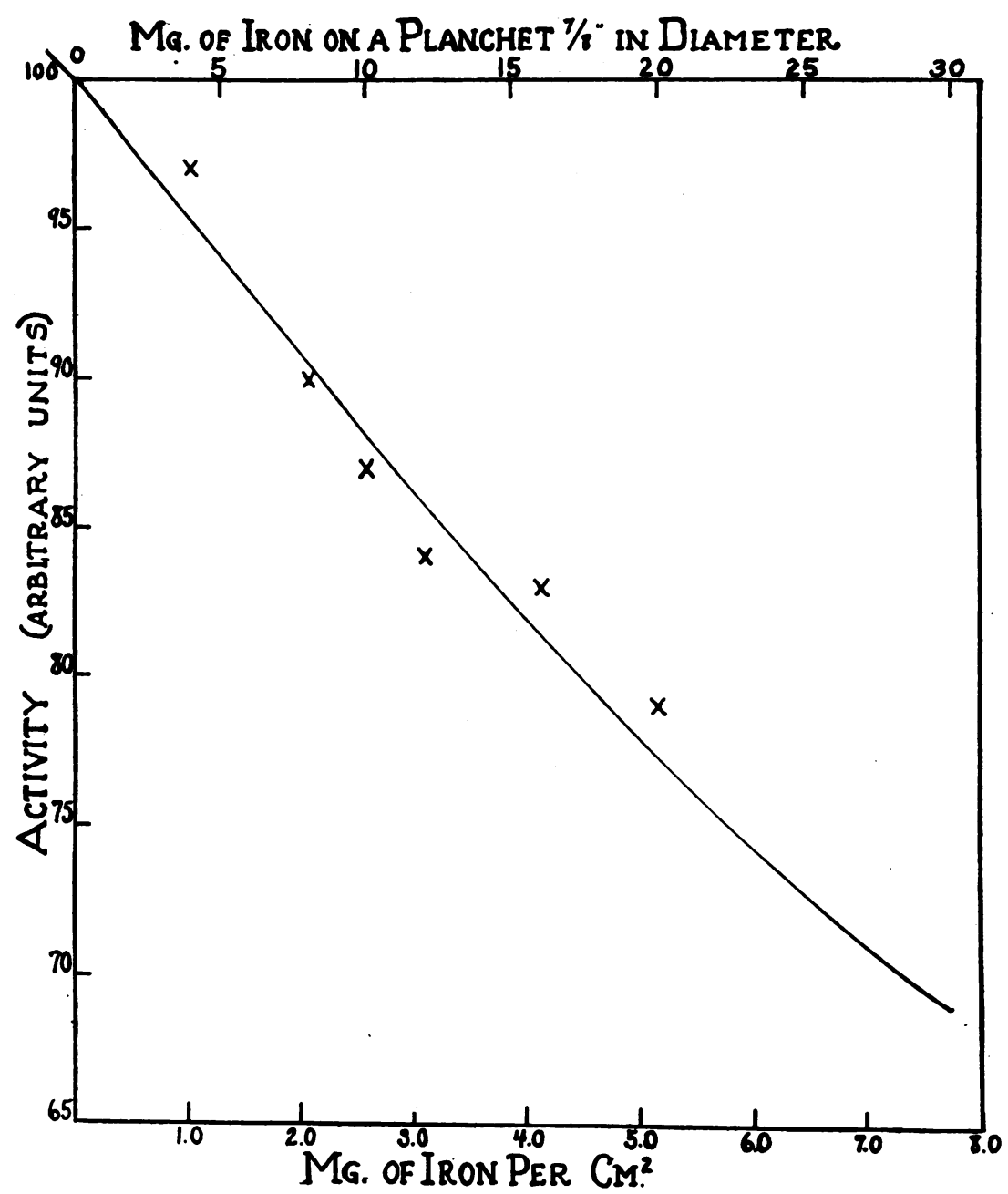

Fig. 4. A Constant Amount of Fe55 and Varying Amounts of Inactive Iron Were Plated Together

The points are proportional to the measured activities and the solid curve is the predicted activity if all detected radiation is the $\mathrm{K}$ x-rays associated with this isotope. Both the curve and the experimental points are normalized to 100 at zero thickness of iron. 


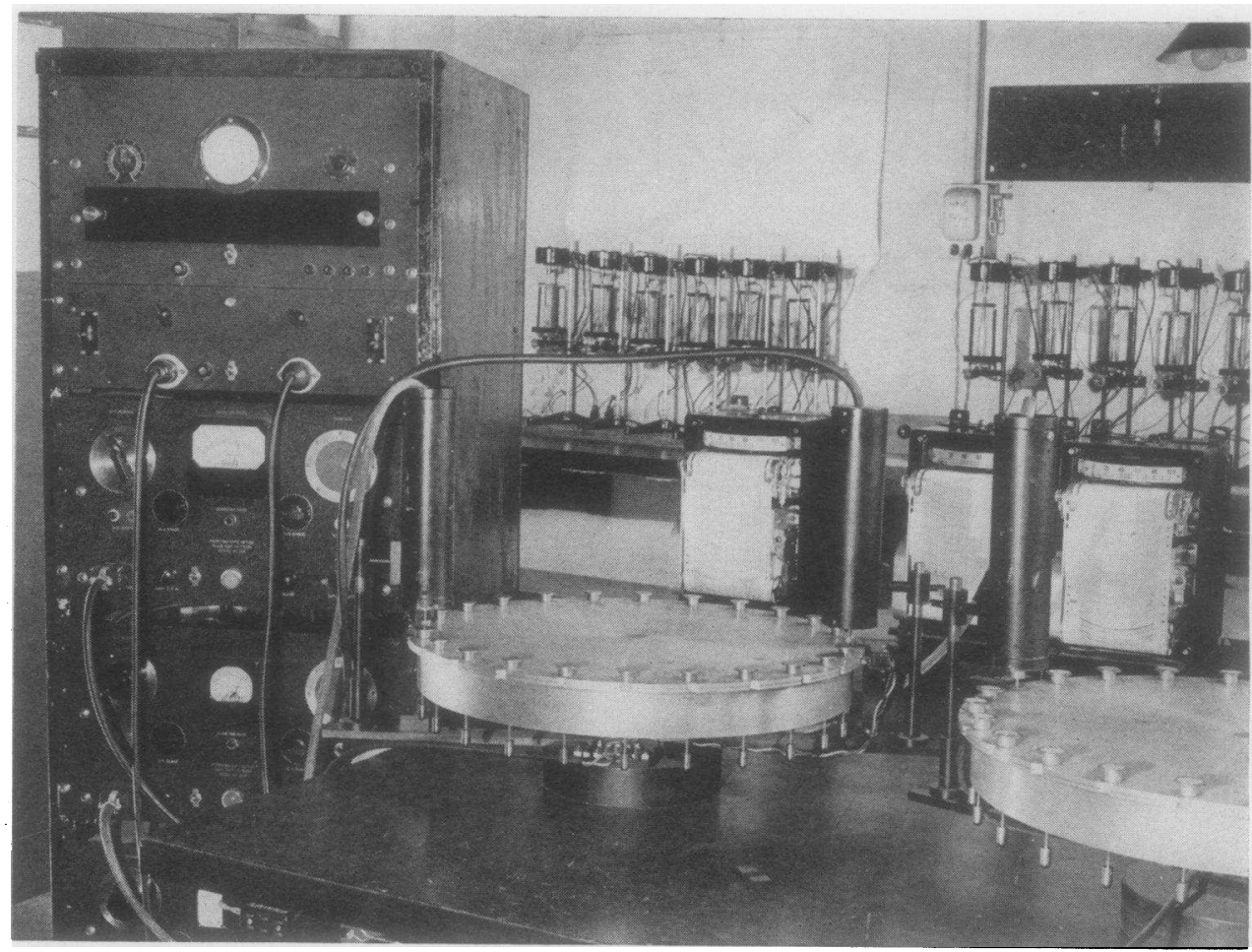

Fig. 5. Apparatus for Measuring the Radioactivity of $\mathrm{F}^{55}$ and $\mathrm{F}^{59}$ Samples

Two batteries of electroplaters appear in the background. A beta ray counter is mounted on the left and an $\mathbf{x}$-ray counter on the right side of the automatic sample changer, in center foreground. Planchets are secured to the plungers. The turntable rotates through $15^{\circ}$ every 15 minutes; the counted planchet drops, and the next sample is moved up close to the counter window. Counting rate meters and calibrating apparatus appear at the left, and the pen and ink recorders in the middle background.

and an x-ray counter are obtained separately and simultaneously and on separate charts, simply by putting both types of counters over the same turntable.

To insure accuracy in measurement, the apparatus is checked regularly for changes in calibration, background, or counter sensitivity.

\section{METHOD OF REPORTING RESULTS}

All activity measurements are reported in terms of "unit activity" or Ua. We obtain this quantity as follows: the background counting rate is subtracted from each sample reading to give net counts per minute. Net counts per minute in a sample are divided by the total volume of red cells in the sample and the net counts per minute in the radioactive standard used. The radioactive standard is an aliquot of the radioactive material originally administered to the subjects used in the experiment. Thus $\mathrm{Ua}$ is independent of radioactive decay and counter sensitivity. $\mathrm{Ua}$ is proportional to the relative concentration of radioactive iron found in the various samples measured. From the known weight of iron in the aliquot used as the standard, one can readily calculate the number of micrograms of tagged iron corresponding to a $\mathrm{Ua}$ of one.

Suppose for example 1 ampul of 5 year iron contained 1 million counts per minute as detected at a particular time on an x-ray counter, and that there was $1 \mathrm{mgm}$. of iron in the ampul. Three thousand counts per minute would be a convenient counting rate, so a standard would be prepared containing 3 micrograms of radioactive iron and $10 \mathrm{mgm}$. of inactive iron. A sample of red cells having 1500 counts per minute per $\mathrm{ml}$. would have a $\mathrm{Ua}$ of 0.50 . Assuming all this activity was from the same iron target as the stand- 
ard, the blood would contain 1.5 micrograms of the tagged iron from the target per ml. of red cells. It is worth while emphasizing at this point, however, that standards of 5 year iron that are used continuously for a period of weeks will not have the same counting rate at the end of this time as samples freshly plated. This is due to the absorption of the radiation in a thin oxide film that forms over the planchet surface.

\section{RADIATION RECEIVED BY A DONOR WITH RADIOACTIVE BLOOD}

There is one more important consideration in connection with the physical aspect of this study, i.e. radiation that will be received by the donor to whom the radioactive isotopes are given.

The activity a donor's blood should have varies with the type of experiment being performed. Let us take as an example a case where about 3000 counts per minute per ml. of donor red cells are necessary in order to obtain sufficient activity in the recipient cells with either isotope.

The present beta ray counters detect approximately 25 per cent of the disintegrations of $\mathrm{Fe}^{59}$, and the $x$-ray counters detect approximately 3 per cent of the disintegrations of $\mathrm{Fe}^{55}$.

We can assume that essentially all of the gamma ray radiation of $\mathrm{Fe}^{59}$ is absorbed outside the blood stream, and that the large majority of it is not stopped inside the body at all. The beta rays of $\mathrm{Fe}^{59}$ have a maximum energy of $0.46 \mathrm{MEV}$ and an average energy of $0.12 \mathrm{MEV}$. Hence (17) their maximum range is about $1.5 \mathrm{~mm}$., and their average range is about $0.15 \mathrm{~mm}$. of blood or surrounding tissue. The mass absorption coefficients (Table I) for the $\mathrm{x}$-rays of $\mathrm{Fe}^{55}$ (5.9 kv.) show

TABLE I

\begin{tabular}{l|c|c}
\hline \hline \multicolumn{1}{c|}{ Material } & $\begin{array}{c}\text { Mass absorption } \\
\text { coefficient in } \\
\text { cm² }^{2} \text { per gram }\end{array}$ & $\begin{array}{c}\text { Thickness in cm. } \\
\text { necessary to re- } \\
\text { duce intensity } \\
\text { to half }\end{array}$ \\
\hline He (gas at S.T.P.) & 0.5 & 7800. \\
Be & 4.3 & 0.087 \\
Carbon (graphite) & 11. & 0.028 \\
Oxygen (gas at S.T.P.) & 28. & 17.5 \\
Mica* & 210. & 0.0012 \\
Aluminum & 130. & 0.0019 \\
Iron & 100. & 0.00087 \\
Argon (gas at S.T.P.) & 286. & 1.35 \\
Gold & 480. & 0.000076 \\
\hline
\end{tabular}

$* \mathrm{~K}_{2} \mathrm{O} \cdot 3 \mathrm{Al}_{2} \mathrm{O}_{3} \cdot 6 \mathrm{SiO}_{2} \cdot 2 \mathrm{H}_{2} \mathrm{O}$. that these rays are also absorbed in a comparably short distance in tissue. We can obtain a sufficiently accurate numerical estimate of the maximum radiation dose by assuming that all the beta rays and $\mathrm{x}$-rays are completely absorbed within the blood stream. The actual radiation dose per gram will be somewhat less than this estimate, because of the portion of the rays absorbed by tissues, especially those surrounding the smaller blood channels.

In $x$-ray practice, tissue radiation doses are expressed in roentgen units, and it is convenient to express the radiation doses due to radioactive isotopes in these same units. One roentgen is that quantity of radiation which produces 1 electrostatic unit (esu) of ions, of both signs, in $1 \mathrm{ml}$. $(0.001293 \mathrm{gram})$ of air at $0^{\circ} \mathrm{C}$. and $760 \mathrm{~mm}$. $\mathrm{Hg}$ pressure. Because each ion carries a charge of $4.80 \times 15^{-10} \mathrm{esu}, 1$ roentgen amounts to $1 /(4.80 \times$ $\left.10^{-10} \times 0.001293\right)=1.61 \times 10^{12}$ ion pairs per gram of air. The average amount of energy required to produce 1 ion pair in air is (18) 32.5 electron volts, or $32.5 \times 1.60 \times 10^{-12}=52 \times 10^{-12}$ ergs. Because tissue is composed of elements having a low atomic weight similar to air, the energy required to form an ion pair in tissue may be taken as the same as the energy required to form an ion pair in air. 'Then 1 roentgen represents an energy expenditure in each gram of tissue of $32.5 \times 1.61 \times 10^{12}=52 \times 10^{12}$ electron volts, or of $52 \times 10^{-12} \times 1.61 \times 10^{12}=84$ ergs.

One ml. of donor blood, at a hematocrit of 40 per cent, will then contain $3000 \times 0.4=1200$ c.p.m. When the efficiency of the counters is considered, these counting rates correspond to the disintegration of $1200 / 0.25=4800$ atoms of $\mathrm{Fe}^{\mathrm{\sigma \theta}}$, or of $1200 / 0.03=40,000$ atoms of $\mathrm{Fe}^{55}$.

The maximum energy delivered per gram $(0.95$ ml.) of blood by $\mathrm{Fe}^{58}$ is thus $4800 \times 0.95 \times 0.12$ $\times 10^{8}=5.5 \times 10^{8}$ electron volts per minute or $5.5 \times 10^{12}$ electron volts per week, or $5.5 \times$ $10^{12} / 52 \times 10^{12}=0.11$ roentgen per week.

Similarly, the maximum energy delivered per gram of blood by $\mathrm{Fe}^{55}$ is $40,000 \times 0.95 \times 5.9 \times$ $10^{3}=2.2 \times 10^{8}$ electron volts per minute or $2.2 \times$ $10^{12}$ electron volts per week, or $2.2 \times 10^{12} / 52 \times$ $10^{12}=0.04$ roentgen per week.

Thus the radiation dose from either isotope in a donor may be taken as 0.1 roentgen per week in 
the blood stream only, and a negligible dose in the rest of the body tissues. Alternately, if the radiation is assumed distributed uniformly through all the body tissues, then the whole body radiation dose is about 0.007 roentgen per week for $\mathrm{Fe}^{59}$ donors, and 0.003 for $\mathrm{Fe}^{55}$ donors. In recipients the radiation doses are much smaller than in the donors, usually by a factor of 50 .

The tolerance dose for continuous whole-body exposure is 0.1 roentgen per day, or about 1 roentgen per week to all the tissues of the body (19).

It is evident that no radiation effects are to be expected, and none have been observed. We have built up a total of 48 human donors. Three received the isotopes $\mathrm{Fe}^{55}$ and $\mathrm{Fe}^{59}$ mixed (produced by bombardment of an iron target), 6 received $\mathrm{Fe}^{58}$, and 38 received $\mathrm{Fe}^{55}, 3$ of the latter also receiving subsequent doses of $\mathrm{Fe}^{59}$. The calculated dosages in these donors have ranged from 0.05 to 0.2 roentgens per week. Three of these subjects have been observed over a period of 4 years, 8 for from 12 to 19 months, and 36 for from 2 to 10 months.

Red cells from these donors have been transfused into 160 human recipients in amounts ranging from 50 to $250 \mathrm{ml}$. These subjects have been under observation for from 2 months to 4 years.

All of these subjects were normal young adult males, with active daily routines. In no instance has any change in blood picture occurred, as evidenced by changes in hematocrit or hemoglobin levels (other than could be accounted for by bleeding), or change in leucocyte count. Regeneration of red cells following bleeding has apparently been normal, and several donors have been bled more than once. Three subjects have married subsequent to receiving radio-iron, and have begotten normal children.

In addition, radio-iron, in dosages about equivalent to that received by recipients, has been given to 65 patients on the wards of the Peter Bent Brigham Hospital, without observed radiation effects. Many of these patients had anemias, and yet the course of recovery from hemorrhage appeared to be unaffected by the radiation.

SUMMARY

1. Two radioactive isotopes of iron, $\mathrm{Fe}^{59}$ (47 day half life) and $\mathrm{Fe}^{55}$ ( 5 year half life), are pro- duced separately and obtained in a state of radioactive purity. These isotopes are prepared in the form of ferric ammonium citrate for intravenous injection into human subjects. The radiation doses in donors and recipients are well below accepted tolerance levels.

2. Blood and tissue samples are prepared for radioactive measurement by $\mathrm{H}_{2} \mathrm{SO}_{4}-\mathrm{HClO}_{4}$ digestion and ammoniacal precipitation. The iron in the sample is electroplated from an ammonium oxalate-oxalic acid solution onto a copper disk.

3. Routine measurements are reported in terms of "unit activity" which is a ratio of sample to a standard aliquot of the original activity. Corrections for decay during an experiment are thus eliminated.

4. Geiger-Müller counters are described, which discriminate between the 2 isotopes of iron when both are present in the same biological sample, thus permitting double-tracer experiments.

We wish to acknowledge the help we have received from N. J. Grant of the Metallurgy Department, in the preparation of the manganese targets; Prof. M. S. Livingston, Dr. Eric T. Clark and the M. I. T. Cyclotron crew for the many bombardments; Rose Clopman, Martha Weeks, Florence Tytell and Eleanor Ryan for preparing and measuring several thousand samples using this technique.

\section{BIBLIOGRAPHY}

1. Hahn, P. F., Bale, W. F., Lawrence, E. O., and Whipple, G. H., Radioactive iron and its metabolism in anemia. J. Exper. Med., 1939, 69, 739.

2. Hahn, P. F., Bale, W. F., Hettig, R. A., Kamen, M. D., and Whipple, G. H., Radioactive iron and its excretion in urine, bile, and feces. J. Exper. Med., 1939, 70, 443.

3. Hahn, P. F., Ross, J. F., Bale, W. F., and Whipple, G. H., The utilization of iron and the rapidity of hemoglobin formation in anemia due to blood loss. J. Exper. Med., 1940, 71, 731.

4. Balfour, W. M., Hahn, P. F., Bale, W. F., Pommerenke, W. T., and Whipple, G. H., Radioactive iron absorption in clinical conditions: Normal, pregnancy, anemia, and hemochromatosis. J. Exper. Med., 1942, 76, 15.

5. Hahn, P. F., Bale, W. F., Ross, J. F., Balfour, W. M., and Whipple, G. H., Radioactive iron absorption by gastro-intestinal tract. J. Exper. Med., 1943, 78, 169.

6. Ross, J. F., and Chapin, M. A., The electrolytic separation of radioactive iron from the blood. Rev. Scient. Instruments, 1942, 13, 77. 
7. Livingston, M. S., The cyclotron II. J. Appl. Physics, 1944, 15, 128.

8. Ray, T. W., A rapid means of obtaining manganesefree iron. J. Lab. and Clin. Med., 1940, 25, 745.

9. Hildebrand, W. F., and Lundell, G. E. F., Applied Inorganic Analysis. John Wiley and Sons, New York, 1929, p. 109.

10. Hahn, P. F., Granick, S., Bale, W. F., and Michaelis, L., Ferritin: VI. Conversion of inorganic and hemoglobin iron into ferritin iron in the animal body. Storage function of ferritin iron as shown by radioactive and magnetic measurements. $\mathrm{J}$. Biol. Chem., 1943, 150, 407.

11. Chang, H. C., and Harrop, G. A., Jr., The determination of the circulating blood volume with carbon monoxide. J. Clin. Invest., 1928, 5, 393.

12. Hahn, L., and Hevesy, G., A method of blood volume determination. Acta Med. Scandinav., 1940, 1, 3.

13. Gibson, J. G., 2nd, Weiss, S., Evans, R. D., Peacock, W. C., Irvine, J. W., Jr., Good, W., and Kip, A. F., The measurement of circulating red cell volume by means of two radioactive istopes of iron. J. Clin. Invest., 1946, 25, 616.

14. Gibșon, J. G., 2nd, Aub, J. C., Evans, R. D., Peacock, W. C., Irvine, J. W., Jr., and Sack, T., The measurement of post-transfusion survival of preserved human erythrocytes by means of two isotopes of radioactive iron. In preparation for publication.

15. Classen, A., and von Reis, M. A., Electrolytische Bestimmungen und Trennungen. Berichte, 1881, 14, 1622.

16. Deutsch, M., Downing, J. R., Elliott, L. G., Irvine, J. W., Jr., and Roberts, A., Disintegration schemes of radioactive substances. IV. $\mathrm{Fe}^{59}$. Physiol. Rev., 1942, 62, 3.

17. Evans, R. D., Isotopes, radioactive, measurement. Med. Phys. Yr. Bk. Publishers, 1944, p. 643.

18. Gray, L. H., An ionization method for the absolute measurement of gamma ray energy. Proc. Roy. Soc. London, 1936, 156A, 578.

19. Radium protection. National Bureau of Standards Handbook No. 23, 1938. 